\title{
Characterization of New Bioactive Enzyme Inhibitors from Endophytic Bacillus amyloliquefaciens RWL-1
}

\author{
Raheem Shahzad ${ }^{1}$, Abdul Latif Khan ${ }^{2}$, Liaqat Ali ${ }^{2,3}$, Saqib Bilal ${ }^{1}$, Muhammad Imran ${ }^{1}$, \\ Kyung-Sook Choi ${ }^{4}$, Ahmed Al-Harrasi ${ }^{2}$ and In-Jung Lee ${ }^{1, *}$ \\ 1 School of Applied Biosciences, Kyungpook National University, Daegu 41566, Korea; \\ raheemshehzad@ymail.com (R.S.); saqib043@yahoo.com (S.B.); m.imran02@yahoo.com (M.I.) \\ 2 UoN Chair of Oman's Medicinal Plants \& Marine Natural Products, University of Nizwa, \\ Nizwa 616, Oman; latifepm78@yahoo.co.uk (A.L.K.); malikhejric@gmail.com (L.A.); \\ aharrasi@unizwa.edu.om (A.A.-H.) \\ 3 Department of Chemistry, University of Sargodha, Sub-Campus Mianwali, Mianwali 42200, Pakistan \\ 4 School of Agricultural Civil \& Bio-Industrial Machinery Engineering, Kyungpook National University, \\ Daegu 41566, Korea; ks.choi@knu.ac.kr \\ * Correspondence: ijlee@knu.ac.kr; Tel.: +82-53-950-5708; Fax: +82-53-958-6880
}

Received: 24 November 2017; Accepted: 4 January 2018; Published: 5 January 2018

\begin{abstract}
Endophytic bacteria are known to produce a wide array of bioactive secondary metabolites with beneficial effects on human health. In the current study, a novel endophytic bacterial strain, Bacillus amyloliquefaciens RWL-1, was isolated from the seeds of Oryza sativa. Initially, the crude extract of RWL-1 was assessed for potential biological effects of enzyme inhibition and cytotoxicity and was found to exhibit a broad spectrum inhibition for $\alpha$-glucosidase $(37 \pm 0.09 \%)$ and urease $(49.4 \pm 0.53 \%)$. The screening results were followed by bioassay-guided isolation of secondary metabolite(s) from RWL-1. Extensive chromatographic and spectrophotometry analyses revealed the presence of compound 1 (S)-2-hydroxy-N-((S)-1-((S)-8-hydroxy-1-oxoisochroman-3-yl)-3-methylbutyl)-2((S)-5-oxo-2,5-dihydrofuran-2-yl)acetamide. Further bioassays of compound 1 showed significant inhibition of $\alpha$-glucosidase ( $52.98 \pm 0.8 \%$ ) and urease (51.27 $\pm 1.0 \%)$, compared with positive control values of $79.14 \pm 1.9 \%$ and $88.24 \pm 2.2 \%$, and negative controls $(0.08 \pm 0.1 \%$ and $0.05 \pm 0.01 \%)$, respectively. The current study suggests that bacterial endophytes are a rich source of novel bioactive compounds with high therapeutic value.
\end{abstract}

Keywords: endophytes; biological potential; secondary metabolites; $\alpha$-glucosidase; urease

\section{Introduction}

The term "endophyte" refers to microorganisms (e.g., bacteria, fungi) that live inside plant tissues without causing apparent diseases and have the ability to colonize the internal tissues of the plant $[1,2]$. Endophytes are pervasive in all plant parts and have been isolated from different plant parts [3]. They form mutualistic relationships with host plants, which are either obligatory or facultative associations, and do not damage the host plant; however, this mutualistic interaction also depends on many factors and can change over time [1,3-5]. In this extended symbiotic relationship, the plants provide shelter, protection, and access to essential nutrients; in return, the endophytes generate a beneficial correlation with the host through the modulation of endogenous phytohormones and nutrients, and improve the adaptability of plants to rapidly changing environments [6,7]. Although endophytes are present in all plant species, endophyte-host interaction has not been completely explored. This may include competitiveness in the host tissues mediated by the secretion of secondary metabolites and the detoxification of such inhibitors delivered by endophytes $[8,9]$. 
In addition to plant-microbe interactions, endophytes display many important biological activities [6,10]. Among endophytes, many endophytic bacteria are known to produce a diverse range of bioactive and health-promoting compounds, such as volatile organic compounds, antibiotics, immunosuppressant compounds, and anticancer, antiviral and antifungal drugs [11-13]. More than $60 \%$ of anticancer drugs in clinical use are natural products [14]. The first study of the endophytic bacteria Bacillus amyloliquefaciens afforded the discovery of an antitumor exopolysaccharide derived from the Bacillus genus [15]. In addition to antitumor compounds, the endophytes belonging to the Bacillus genus produce a variety of secondary metabolites; for example, $B$. thuringiensis produces the anti-infective compound anthracene [16] and B. subtilis produces the antimicrobial protein YbdN [17]. These results indicate the promising medicinal potential of the Bacillus genus. Owing to their involvement in phytostimulation, disease suppression, and other biological activities, Bacillus sp. are preferred because their long-term viability can facilitate the development of natural products suitable for commercial use [18].

B. amyloliquefaciens strains have attracted considerable interest because they are able to produce a wide range of active antimicrobial compounds, macrolactins, lipopeptides, hydrolytic enzymes, and certain volatile compounds. For example, B. amyloliquefaciens FZB42 has 8.5\% of its genome dedicated to the synthesis of secondary metabolites [19], allowing the production of lipopeptides, surfactin, fengycin, bacillomycin D, polyketide (difficidin), dipeptide bacilysin, chitin, and colloidal chitin [20,21].

B. amyloliquefaciens produce a variety of secondary metabolites, and previously, RWL-1 was isolated from rice seeds and was identified as B. amyloliquefaciens. RWL-1 was submitted to NCBI under the accession number (KR677384) and was reported to stimulate phytohormone and secondary metabolite production, promote plant growth, and ameliorate stress [1,22,23]. Therefore, given the medicinal potential of B. amyloliquefaciens, the current study aimed to explore the medicinal potential of RWL-1. The ethyl acetate extract of RWL-1 was subjected to biological assays for anticancer, anti-AChE, anti- $\alpha$-glucosidase, and anti-urease activity (Figure 1 ). The positive screening results led to the assessment of RWL-1 by advanced chromatographic and NMR spectroscopic techniques to isolate the secondary metabolites responsible for $\alpha$-glucosidase and urease inhibition. A secondary metabolite (Figure 2) was purified and the chemical structure was deduced from MS and NMR data analysis and comparison with the literature values [24]. The purified secondary metabolite was subjected to a urease inhibition bioassay to evaluate and confirm its medicinal potential.
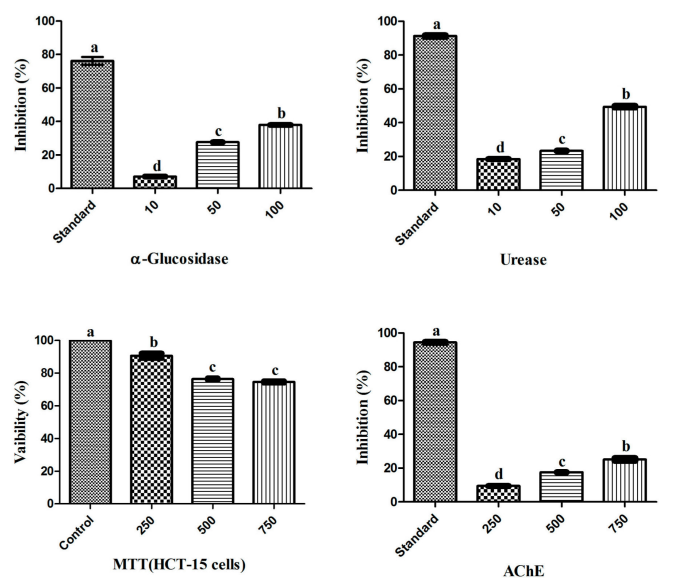

Figure 1. Biological potential of endophytic RWL-1 crude extract. The graph values are presented as the mean of three replicates with standard error. The acarbose, thiourea, DMSO and galantamine was used as reference standard for $\alpha$-Glucosidase, Urease, MTT (HCT-15 cells) and AChE inhibition respectively. Bars with different letters are significantly different at $p \leq 0.05$ based on Duncan multiple range test. 


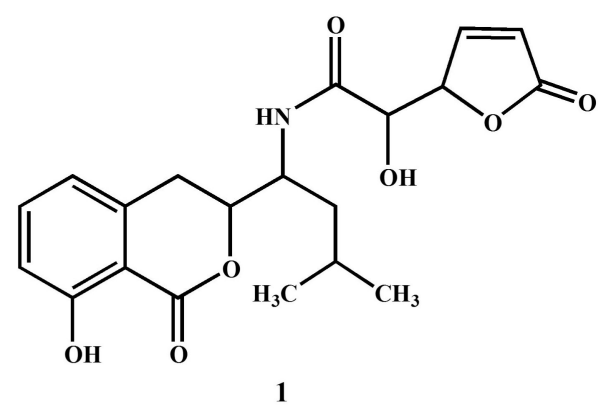

Figure 2. Nuclear magnetic resonance spectroscopic analysis of compound 1 ((S)-2-hydroxy-N((S)-1-((S)-8-hydroxy-1-oxoisochroman-3-yl)-3-methylbutyl)-2-((S)-5-oxo-2,5-dihydrofuran-2-yl)acetamide).

\section{Materials and Methods}

\subsection{Bacterial Growth Conditions}

RWL-1 was grown in 8 L of LB medium (tryptone, $10 \mathrm{~g}$; yeast extract, $5 \mathrm{~g}$; sodium chloride, $10 \mathrm{~g}$; pH $7.0 \pm 0.2$; autoclaved for $15 \mathrm{~min}$ at $121^{\circ} \mathrm{C}$ ). The inoculated RWL-1 was incubated on shaking incubator $(120 \mathrm{rpm})$ for 7 days at $28^{\circ} \mathrm{C}$ and centrifuged at $5000 \times g$ for $15 \mathrm{~min}$ to separate the cells from the culture broth.

\subsection{Extraction for Secondary Metabolite Identification}

The cell-free culture broth of RWL-1 was adjusted to $\mathrm{pH} 2.5$ and was completely extracted three times with an equal volume of ethyl acetate (EtOAc). The ethyl acetate extract was then completely dried in a rotary evaporator to obtain the crude extract $(1.6 \mathrm{~g})$. The ethyl acetate crude extract was subjected to various biological assays for the assessment of its medicinal potential.

\subsection{Secondary Metabolite Isolation}

Based on the results of the bioassay, the ethyl acetate extract was analyzed by silica gel column chromatography using a solvent gradient (1\% EtOAc/n-hexane to 85\% EtOAc/n-hexane). TLC (pre-coated aluminum sheets, silica gel 60F-254, E. Merck, Darmstadt, Germany) experiments were performed to investigate and determine the different fractions of organic extract of bacterial culture broth. The TLC plates were observed under UV light at 254 and $365 \mathrm{~nm}$ (Vilber Lourmate, Marne-la-Vallee, France).

\subsection{Reverse-Phase HPLC Analysis}

To achieve further purification, the bioactive fractions were subjected to recycling preparative high-performance liquid chromatography (HPLC) using a Shimadzu device CBM-10 (Varian, Inc., Palo Alto, CA, USA) coupled with a UV-VIS detector (SPD-10A, SpectraLab Scientific Inc., Markham, $\mathrm{ON}$, Canada). The sample was loaded onto a $\mathrm{C}_{18}$ column (Luna $5 \mu \mathrm{m}, 100 \AA, 250 \mathrm{~mm} \times 4.60 \mathrm{~mm}$ ) equipped with pumps A and B (LC-10AD). A solvent gradient of Solvent A-100\% MeOH and Solvent B-Water with 5\% acetic acid with Solvent program: 0-20 min (50\% = A; 50\% = B), 20-40 $\min (80 \% \mathrm{~A}$, $20 \% \mathrm{~B}), 40-60 \mathrm{~min}(100 \% \mathrm{~A}, 0 \% \mathrm{~B})$ was used at a flow rate of $1 \mathrm{~mL} / \mathrm{min}$. The remaining impurities were removed by loading the semi-pure secondary metabolite on preparative TLC plates (as described in "Secondary metabolite isolation") and compound $\mathbf{1}$ (4.5 mg) was purified in DCM/n-hexane (95:5).

\subsection{Structure Elucidation of Compound $\mathbf{1}$}

The purified compound 1 was subjected to spectroscopic analyses (UV, IR, ${ }^{1} \mathrm{H}-\mathrm{NMR},{ }^{13} \mathrm{C}-\mathrm{NMR}$, ESI, and MS/MS studies) for identification and characterization. The optical measurements were conducted by using a polarimeter (JASCO DIP360, Jasco Co., Tokyo, Japan). A Bruker ATR-Tensor 
37 spectrophotometer (Bruker, Ettlingen, Germany) was used to record the IR spectra. To obtain the ESI mass spectra, a QSTAR mass spectrometer (Applied Biosystems, Foster, CA, USA) with capillary voltage of $5-5.5 \mathrm{kV}$ was used. The NMR spectra $\left({ }^{1} \mathrm{H}\right.$ and $\left.{ }^{13} \mathrm{C}\right)$ were obtained by using a Bruker NMR spectrometer (Burker, Fallanden, Switzerland) operated at $600 \mathrm{MHz}$ and $150 \mathrm{MHz}$, respectively.

\subsection{In Vitro Biological Activities of RWL-1 Crude Extract}

\subsubsection{Urease Inhibition}

The inhibitory effects of the ethyl acetate crude extract and compound 1 on urease activity was measured in accordance with the method of [25]. Briefly, $100 \mathrm{mM}$ urea $(0.055 \mathrm{~mL})$ in $8.2 \mathrm{pH}$ phosphate buffer containing $0.01 \mathrm{M} \mathrm{LiCl}_{2}, 0.1 \mathrm{mM}$ EDTA, and $0.01 \mathrm{M} \mathrm{K}_{2} \mathrm{HPO}_{4} \cdot 3 \mathrm{H}_{2} \mathrm{O}$ was reacted with 3 units $/ \mathrm{mL}$ jack bean urease $(0.025 \mathrm{~mL})$ (Sigma, Munich, Germany) and various concentrations of crude extract

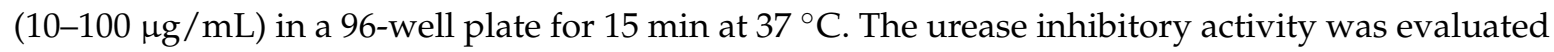
through the measurement of ammonia production by the indophenol blue method. The absorbance was measured at $630 \mathrm{~nm}$ and thiourea was used as the standard inhibitor. The inhibition percentage was calculated from the following equation:

$$
\text { Inhibition }(\%)=100-\left(\mathrm{OD}_{\text {test }} / \mathrm{OD}_{\text {control }}\right) \times 100
$$

\subsection{2. $\alpha$-Glucosidase Inhibition}

The inhibitory effects of the ethyl acetate crude extract and compound $\mathbf{1}$ on $\alpha$-glucosidase activity were measured in accordance with the method of [26]. Briefly, $\alpha$-glucosidase was mixed with different concentrations of RWL-1 ethyl acetate crude extract and incubated for $10 \mathrm{~min}$ at $37^{\circ} \mathrm{C}$. Acarbose was used as a positive control and $p$-nitrophenyl $\alpha$-D-glucopyranoside (PNP-G) was used as the substrate. The absorbance of $p$-nitrophenol released from $p$ NPG was measured at $405 \mathrm{~nm}$ every $5 \mathrm{~min}$. The inhibition percentage was calculated from the standard curve.

\subsubsection{Anticancer Assay (MTT)}

The effect of the ethyl acetate crude extract and compound 1 on cell viability was evaluated by an MTT assay in accordance with the protocol described by [27]. Briefly, HCT-15 cells were purchased from American Type Culture Collection CCL-25 (USA) and were maintained at $37^{\circ} \mathrm{C}$ in subconfluent conditions in a humidified atmosphere of $95 \%$ air and $5 \% \mathrm{CO}_{2}$. RPM- 1640 medium supplemented with $10 \%$ fetal bovine serum and $1 \%(v / v)$ streptomycin was used for subculturing. HCT-15 cells were subcultured at density of $10^{5}$ cells/well in 96-well plates with and without different concentrations (250, 500 and $750 \mu \mathrm{g} / \mathrm{mL}$ ) of ethyl acetate crude extract of RWL-1 for 24, 48, and $72 \mathrm{~h}$. The medium was removed and $20 \mu \mathrm{L}$ MTT solution $(5 \mathrm{mg} / \mathrm{mL}$ in PBS) was added to each well of the 96-well plate and incubated for $2 \mathrm{~h}$ at $37^{\circ} \mathrm{C}$. After incubation, the MTT medium was replaced with DMSO $(200 \mu \mathrm{L})$. The plate was gently shaken for $1 \mathrm{~min}$ and the absorbance was measured at $540 \mathrm{~nm}$. The following equation was used for the calculation of cell viability:

$$
\text { Viable cells }(\%)=(\mathrm{OD} \text { of treated sample } / \mathrm{OD} \text { of untreated sample }) \times 100
$$

\subsubsection{AChE Inhibition}

The AChE inhibition assay was conducted in accordance with the protocol described by [28] using a slightly modified version of Ellman's colorimetric method. Briefly, $15 \mathrm{mM}$ acetylthiocholine iodide in deionized water $(25 \mu \mathrm{L})$ and $3 \mathrm{mM} 5,5$-dithiobis-2-nitrobenzoic acid (DTNB) $(125 \mu \mathrm{L})$ in $50 \mathrm{mM}$ Tris- $\mathrm{HCl}$ buffer, $\mathrm{pH} 8.0$, containing $0.1 \mathrm{M} \mathrm{NaCl}$ and $0.02 \mathrm{M} \mathrm{MgCl}_{2} \cdot 6 \mathrm{H}_{2} \mathrm{O}$, were added into a 96-well plate. Subsequently, $50 \mathrm{mM}$ Tris- $\mathrm{HCl}$ buffer, $\mathrm{pH} 8.0$, containing $0.1 \%$ bovine serum albumin $(50 \mu \mathrm{L})$ and ethyl acetate crude extract $(25 \mu \mathrm{L})$ were added at different concentration $(50 \mu \mathrm{g} / \mathrm{g}$ to $600 \mu \mathrm{g} / \mathrm{g})$. $\operatorname{AChE}(25 \mu \mathrm{L}, 0.2 \mathrm{U} / \mathrm{mL})$ was added and the absorbance was measured at $412 \mathrm{~nm}$ at $45 \mathrm{~s}$ intervals. 
Galantamine $(0.5-5 \mu \mathrm{g} / \mathrm{mL})$ was used as a standard inhibitor. The inhibition percentage was calculated from the following formula:

$$
\text { Inhibition }(\%)=1-(\text { sample reaction rate/blank reaction rate }) \times 100
$$

\subsection{Statistical Analysis}

The data are presented as the mean \pm S.D. of three replicate experiments. Graphical representations was computed by using GraphPad Prism software 6.01 package (GraphPad Software, Inc., La Jolla, CA, USA) and statistical analyses were conducted with Duncan's multiple range test in SAS version 9.2 (Cary, NC, USA).

\section{Results and Discussion}

\subsection{Biological Potential of RWL-1 Crude Extract}

Throughout history, natural products have consistently been the best source for prominent compounds with a potent role in the fields of agriculture, medicine, and pharmacy [29,30]. Among natural products, microorganisms are considered to contain an abundance of unlimited bioactive metabolites with a high therapeutic value [31]. Recently, scientists have focused on endophytes because of the unique ecological niche these organisms live in [32] and several bioactive compounds with compelling therapeutic applications, such as anticancer, anti-obesity, anti-AChE, and anti- $\alpha$-glucosidase enzymes have been isolated from endophytes $[15,16,26,33]$. However, the isolation, purification, and identification of potent bioactive compounds are particularly laborious and difficult [34]. Therefore, in the current study, the crude extract of endophytic B. amyloliquefaciens RWL-1 was screened for its biological potential.

The biological potential of the RWL-1 crude extract was examined through its inhibitory activity on various enzymes and cytotoxicity (Figure 1). The inhibition of $\alpha$-glucosidase, urease, AChE, and the cytotoxicity of cancerous HCT-15 cells was examined in response to treatment with various concentrations of the RWL-1 crude extract; significant inhibition of $\alpha$-glucosidase and urease was observed, but no significant reduction of AChE activity or HCT-15 cell viability was found (Figure 1).

The crude extract showed inhibition of $\alpha$-glucosidase and urease as the concentration of RWL-1 crude extract increased (10-100 $\mu \mathrm{g} / \mathrm{mL})$. A higher dose $(100 \mu \mathrm{g} / \mathrm{mL})$ significantly inhibited $\alpha$-glucosidase $(37 \pm 0.09 \%)$ and urease $(49.4 \pm 0.53 \%)$, with the positive control leading to $74.85 \pm 0.06 \%$ and $90.86 \pm 0.08 \%$ inhibition, respectively. The cytotoxicity and AChE inhibition of ethyl acetate crude extract of RWL-1 were determined to occur in a dose-dependent manner at relatively high doses $(250-750 \mu \mathrm{g} / \mathrm{mL})$. The inhibition of cell growth was examined after exposure to different concentrations of the ethyl acetate crude extract of RWL-1. The results revealed that the RWL-1 crude extract showed a small cytotoxic effect $(25 \pm 0.16 \%)$ at a higher concentration $(750 \mu \mathrm{g} / \mathrm{mL})$ compared with the control $(100 \%)$. A similar trend was also observed for AChE inhibition. No significant decreases were observed in the AChE activity in response to different concentrations $(250-750 \mu \mathrm{g} / \mathrm{mL})$ of the RWL-1 crude extract, although the positive control compound significantly inhibited AChE $(94.45 \pm 0.31 \%)$.

\subsection{Structural Elucidation of Compound 1}

The structure elucidation of compound 1 was conducted by the analysis of NMR and MS spectral data in comparison with the data reported in previous studies $[24,35,36]$. The $1 \mathrm{H}-\mathrm{NMR}$ spectrum displayed signals for five protons in the aromatic region ( 8 8.76-7.59) owing to tri-substituted benzene and the unsaturated $\gamma$-lactone moieties in the molecule. A broad singlet in the downfield region at $\delta 9.15$ was assigned to the amide proton $\mathrm{NH}$ in the molecule. In addition to these aromatic signals, three oxy-methine protons $(\delta 4.24-3.84)$ and two methyl groups $(6 \mathrm{H}, \mathrm{d}, J=7.4 \mathrm{~Hz})$ were also observed in the ${ }^{1} \mathrm{H}-\mathrm{NMR}$ spectrum. In the ${ }^{13} \mathrm{C}-\mathrm{NMR}$ spectrum, the unsaturated $\gamma$-lactone was indicated by the presence of a carbonyl carbon at $\delta 176.2$, in addition to two 
characteristic $\mathrm{sp}^{2}$ methine signals at $\delta 153.7$ and 132.4. The aromatic methine carbons of the substituted benzene ring appeared at $\delta 139.3,129.9$, and 125.3. The spectral data of compound 1 (Name: (S)-2-hydroxy-N-((S)-1-((S)-8-hydroxy-1-oxoisochroman-3-yl)-3-methylbutyl)-2-((S)-5-oxo-2,5dihydrofuran-2-yl)acetamide) were further compared with those reported in literature $[24,35,36]$. The overall physical and spectral data of compound $\mathbf{1}$ were found to be identical to the reported antibiotic Al 77F, which was previously isolated from bacterial strains of Bacillus pumilus [36] and the fungal strains of Alternaria tenuis [24].

\subsection{Biological Evaluation of Compound $\mathbf{1}$}

Based on the biological potential of the crude extract, the enzyme inhibition potential of compound 1 was evaluated. The inhibition patterns of $\alpha$-glucosidase and urease in response to compound 1 are shown in Figure 3.
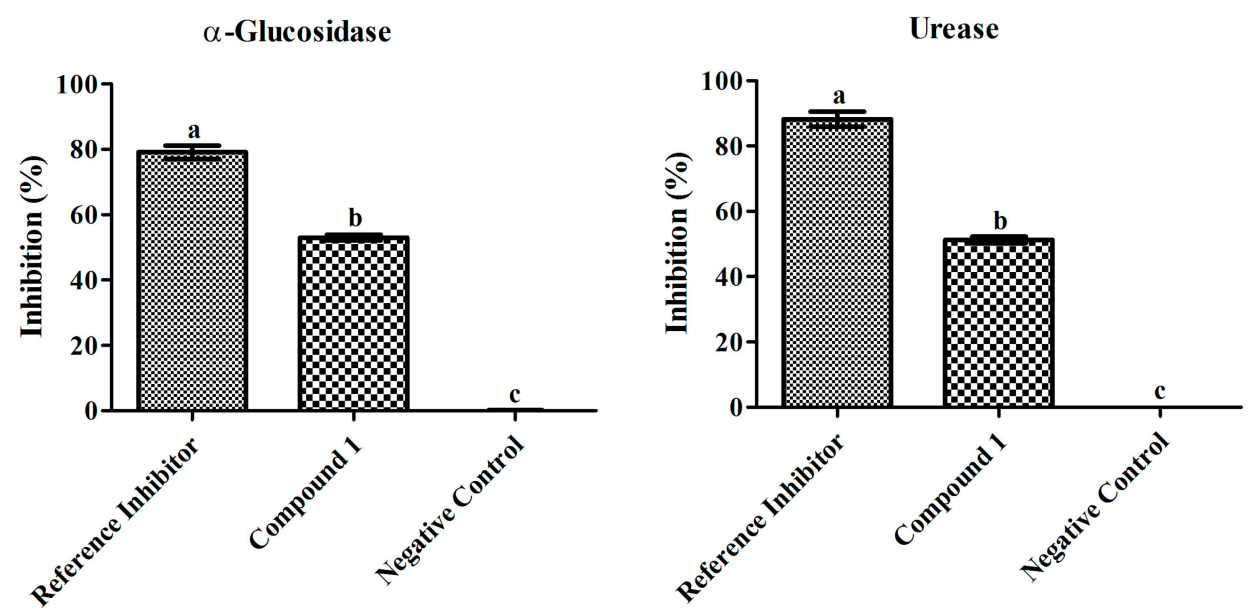

Figure 3. Inhibitory effects of compound $1\left(100 \mu \mathrm{g} \mathrm{mL}^{-1}\right)$ and reference inhibitors $\left(80 \mu \mathrm{g} \mathrm{mL}^{-1}\right)$ on $\alpha$-glucosidase and urease. The graph values are standard error of means of three replications. The acarbose and thiourea was used as reference inhibitor for $\alpha$-glucosidase and urease. Bars with different letters are significantly different at $p \leq 0.05$ based on Duncan multiple range test.

The $\alpha$-glucosidase inhibition efficiency of compound 1 was examined at different doses and the inhibition percentage significantly increased as the concentration increased $(10-100 \mu \mathrm{g} / \mathrm{mL})$ showing $94.37 \mu \mathrm{g} / \mathrm{mL} \mathrm{IC}_{50}$ value. The highest concentration of compound $1(100 \mu \mathrm{g} / \mathrm{mL})$ resulted in the strongest $\alpha$-glucosidase inhibition (52.98 $\pm 0.8 \%)$. However, the standard drug used as the positive control $(10-100 \mu \mathrm{g} / \mathrm{mL})$ resulted in highest inhibition $(79.14 \pm 1.9 \%)$ at $80 \mu \mathrm{g} / \mathrm{mL}$ displaying an $\mathrm{IC}_{50}$ value of $62.03 \mu \mathrm{g} / \mathrm{mL}$, while the negative control resulted in $0.08 \pm 0.1 \%$ inhibition.

The urease inhibition was also evaluated at different doses and the inhibition percentage increased as the concentration of compound 1 increased $(10-100 \mu \mathrm{g} / \mathrm{mL})$ exerting an $\mathrm{IC}_{50}$ value of $97.52 \mu \mathrm{g} / \mathrm{mL}$. The highest dose of compound $1(100 \mu \mathrm{g} / \mathrm{mL})$ marked significant inhibition $(51.27 \pm 1.0 \%)$ and the standard drug used as the positive control resulted in $88.24 \pm 2.2 \%$ at $80 \mu \mathrm{g} / \mathrm{mL}$ with $55.13 \mu \mathrm{g} / \mathrm{mL}$ $\mathrm{IC}_{50}$ value, while the negative control resulted in $0.05 \pm 0.01 \%$ inhibition.

In recent years, interest has intensified in the isolation and identification of bioactive $\alpha$-glucosidase and urease inhibitors that can both be utilized as tools to comprehend biochemical processes and function as prospective therapeutic agents [26,33]. Although plants are a vital source of bioactive metabolites, microbes are also considered an important source of bioactive metabolites with high therapeutic value $[37,38]$. Although the biological potential of B. amyloliquefaciens is widely reported [15], this study is the first to describe the enzyme inhibitory activity of $B$. amyloliquefaciens and the bioactive compounds isolated from this species. Moreover, the biological potential of isolated compound 1 from B. amyloliquefaciens RWL-1 has been reported to have anti-bacterial and antiulcer 
properties $[39,40]$. The results of the current study are in agreement with the findings of other researchers who have reported that endophytes provide plentiful resources from which $\alpha$-glucosidase and urease inhibitors can be found [26,33].

\section{Conclusions}

The current study evaluated the biological potential of endophytic B. amyloliquefaciens RWL-1 and conducted bioassay-guided isolation of bioactive metabolites responsible for enzymes inhibition (Figure 4). The screening of isolated compound 1 (S)-2-hydroxy-N-((S)-1-((S)-8hydroxy-1-oxoisochroman-3-yl)-3-methylbutyl)-2-((S)-5-oxo-2,5-dihydrofuran-2-yl)acetamide supported the observed effects of B. amyloliquefaciens RWL-1 in $\alpha$-glucosidase and urease inhibition. B. amyloliquefaciens is considered an ecologically and economically valuable source for the production of bioactive metabolites. Thus, the current study suggests the importance of endophytic microbes in the search for natural bioactive metabolites with high therapeutic potential.

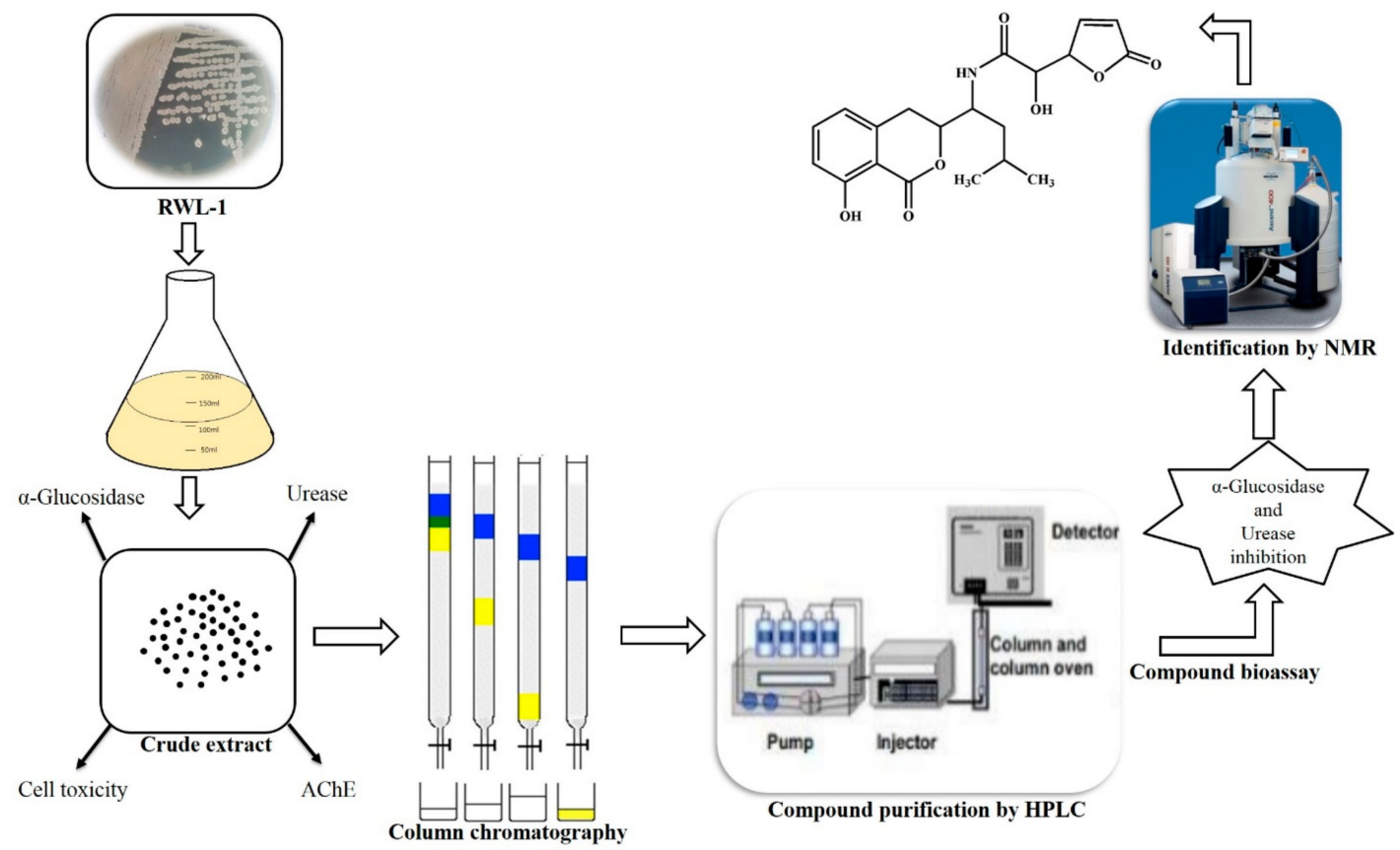

Figure 4. Schematic representation of biological potential of endophytic B. amyloliquefaciens RWL-1 and bioassay guided isolation of bioactive metabolite (Compound 1) for $\alpha$-glucosidase and urease inhibition.

Acknowledgments: This research was supported by Basic Science Research Program through the National Research Foundation of Korea (NRF) funded by the Ministry of Education (2017R1D1A1B04035601).

Author Contributions: R.S. and A.L.K. conceived and designed the experiment. R.S. conducted the experiment, collected the data and wrote the manuscript. S.B. contributed in compound isolation. L.A. contributed in structure elucidation of compound. M.I. helped in conducting the experiment. K.-S.C. contributed in biological assays. A.A.-H. contributed in HPLC and NMR analysis. I.-J.L. supervised the design and conducting of all the experiments, and provided the relevant facilities, financial support, and mentorship.

Conflicts of Interest: The authors declare no conflict of interest.

\section{References}

1. Shahzad, R.; Waqas, M.; Khan, A.L.; Asaf, S.; Khan, M.A.; Kang, S.-M.; Yun, B.-W.; Lee, I.-J. Seed-borne endophytic Bacillus amyloliquefaciens RWL-1 produces gibberellins and regulates endogenous phytohormones of Oryza sativa. Plant Physiol. Biochem. 2016, 106, 236-243. [CrossRef] [PubMed] 
2. Khan, A.L.; Hussain, J.; Al-Harrasi, A.; Al-Rawahi, A.; Lee, I.-J. Endophytic fungi: Resource for gibberellins and crop abiotic stress resistance. Crit. Rev. Biotechnol. 2015, 35, 62-74. [CrossRef] [PubMed]

3. Nair, D.N.; Padmavathy, S. Impact of endophytic microorganisms on plants, environment and humans. Sci. World J. 2014, 2014, 250693. [CrossRef] [PubMed]

4. Hardoim, P.R.; van Overbeek, L.S.; Berg, G.; Pirttilä, A.M.; Compant, S.; Campisano, A.; Döring, M.; Sessitsch, A. The Hidden World within Plants: Ecological and Evolutionary Considerations for Defining Functioning of Microbial Endophytes. Microbiol. Mol. Biol. Rev. 2015, 79, 293-320. [CrossRef] [PubMed]

5. Schulz, B.; Boyle, C. The endophytic continuum. Mycol. Res. 2005, 109. [CrossRef]

6. Strobel, G.A. Endophytes as sources of bioactive products. Microbes Infect. 2003, 5. [CrossRef]

7. Schulz, B.; Boyle, C.; Draeger, S.; Römmert, A.-K.; Krohn, K. Endophytic fungi: A source of novel biologically active secondary metabolites* *Paper presented at the British Mycological Society symposium on Fungal Bioactive Compounds, held at the University of Wales Swansea on 22-27 April 2001. Mycol. Res. 2002, 106, 996-1004. [CrossRef]

8. Saunders, M.; Glenn, A.E.; Kohn, L.M. Exploring the evolutionary ecology of fungal endophytes in agricultural systems: Using functional traits to reveal mechanisms in community processes. Evol. Appl. 2010, 3, 525-537. [CrossRef] [PubMed]

9. Cheplick, G.P.; Faeth, S.H. Ecology and Evolution of the Grass-Endophyte Symbiosis; OUP: New York, NY, USA, 2009; ISBN 0195308085.

10. Schlaeppi, K.; Bulgarelli, D. The Plant Microbiome at Work. Mol. Plant-Microbe Interact. 2014, 28, $212-217$. [CrossRef] [PubMed]

11. Aman, M.; Rai, V.R. Antifungal activity of novel indole derivative from endophytic bacteria Pantoea ananatis 4G-9 against Mycosphaerella musicola. Biocontrol Sci. Technol. 2016, 26, 476-491. [CrossRef]

12. Chen, H.; Yang, C.; Ke, T.; Zhou, M.; Li, Z.; Zhang, M.; Gong, G.; Hou, T. Antimicrobial activity of secondary metabolites from Streptomyces sp. K15, an endophyte in Houttuynia cordata Thunb. Nat. Prod. Res. 2015, 29, 2223-2225. [CrossRef] [PubMed]

13. Shweta, S.; Bindu, J.H.; Raghu, J.; Suma, H.K.; Manjunatha, B.L.; Kumara, P.M.; Ravikanth, G.; Nataraja, K.N.; Ganeshaiah, K.N.; Shaanker, R.U. Isolation of endophytic bacteria producing the anti-cancer alkaloid camptothecine from Miquelia dentata Bedd.(Icacinaceae). Phytomedicine 2013, 20, 913-917. [CrossRef] [PubMed]

14. Abdalla, M.A.; Matasyoh, J.C. Endophytes as producers of peptides: An overview about the recently discovered peptides from endophytic microbes. Nat. Prod. Bioprospect. 2014, 4, 257-270. [CrossRef] [PubMed]

15. Chen, Y.-T.; Yuan, Q.; Shan, L.-T.; Lin, M.-A.; Cheng, D.-Q.; Li, C.-Y. Antitumor activity of bacterial exopolysaccharides from the endophyte Bacillus amyloliquefaciens sp. isolated from Ophiopogon japonicus. Oncol. Lett. 2013, 5, 1787-1792. [PubMed]

16. Roy, S.; Yasmin, S.; Ghosh, S.; Bhattacharya, S.; Banerjee, D. Anti-Infective Metabolites of a Newly Isolated Bacillus thuringiensis KL1 Associated with Kalmegh (Andrographis paniculata Nees.), a Traditional Medicinal Herb. Microbiol. Insights 2016, 9, 1-7. [CrossRef] [PubMed]

17. Jamal, M.T.; Mudarris, M.S.A. Separation of $\mathrm{YbdN}$ bioactive protein from Bacillus subtilis isolated from the Red Sea algae Sargassum sp. with bioactivity against antibiotic resistant bacterial pathogens. Mar. Sci. 2010, 21, 53-64. [CrossRef]

18. Haas, D.; Défago, G. Biological control of soil-borne pathogens by fluorescent pseudomonads. Nat. Rev. Microbiol. 2005, 3, 307-319. [CrossRef] [PubMed]

19. Chen, X.H.; Koumoutsi, A.; Scholz, R.; Eisenreich, A.; Schneider, K.; Heinemeyer, I.; Morgenstern, B.; Voss, B.; Hess, W.R.; Reva, O. Comparative analysis of the complete genome sequence of the plant growth-promoting bacterium Bacillus amyloliquefaciens FZB42. Nat. Biotechnol. 2007, 25, 1007-1014. [CrossRef] [PubMed]

20. Liang, T.-W.; Chen, Y.-J.; Yen, Y.-H.; Wang, S.-L. The antitumor activity of the hydrolysates of chitinous materials hydrolyzed by crude enzyme from Bacillus amyloliquefaciens V656. Process Biochem. 2007, 42, 527-534. [CrossRef]

21. Chen, X.H.; Koumoutsi, A.; Scholz, R.; Schneider, K.; Vater, J.; Süssmuth, R.; Piel, J.; Borriss, R. Genome analysis of Bacillus amyloliquefaciens FZB42 reveals its potential for biocontrol of plant pathogens. J. Biotechnol. 2009, 140, 27-37. [CrossRef] [PubMed] 
22. Shahzad, R.; Khan, A.L.; Bilal, S.; Asaf, S.; Lee, I.-J. Plant growth-promoting endophytic bacteria versus pathogenic infections: An example of Bacillus amyloliquefaciens RWL-1 and Fusarium oxysporum $\mathrm{f}$. sp. lycopersici in tomato. PeerJ 2017, 5, e3107. [CrossRef] [PubMed]

23. Shahzad, R.; Khan, A.L.; Bilal, S.; Waqas, M.; Kang, S.-M.; Lee, I.-J. Inoculation of abscisic acid-producing endophytic bacteria enhances salinity stress tolerance in Oryza sativa. Environ. Exp. Bot. 2017, 136, 68-77. [CrossRef]

24. Liu, J.J.; Huang, B.; Hooi, S.C. Acetyl-keto- $\beta$-boswellic acid inhibits cellular proliferation through a p21-dependent pathway in colon cancer cells. Br. J. Pharmacol. 2006, 148. [CrossRef] [PubMed]

25. Golbabaei, S.; Bazl, R.; Golestanian, S.; Nabati, F.; Omrany, Z.B.; Yousefi, B.; Hajiaghaee, R.; Rezazadeh, S.; Amanlou, M. Urease inhibitory activities of $\beta$-boswellic acid derivatives. DARU J. Pharm. Sci. 2013, 21, 2. [CrossRef] [PubMed]

26. Ali, L.; Khan, A.L.; Al-Kharusi, L.; Hussain, J.; Al-Harrasi, A. New $\alpha$-glucosidase inhibitory triterpenic acid from marine macro green alga Codium dwarkense Boergs. Mar. Drugs 2015, 13, 4344-4356. [CrossRef] [PubMed]

27. Li, J.; Zhao, G.; Chen, H.; Wang, H.; Qin, S.; Zhu, W.; Xu, L.; Jiang, C.; Li, W. Antitumour and antimicrobial activities of endophytic streptomycetes from pharmaceutical plants in rainforest. Lett. Appl. Microbiol. 2008, 47, 574-580. [CrossRef] [PubMed]

28. Moyo, M.; Ndhlala, A.R.; Finnie, J.F.; Van Staden, J. Phenolic composition, antioxidant and acetylcholinesterase inhibitory activities of Sclerocarya birrea and Harpephyllum caffrum (Anacardiaceae) extracts. Food Chem. 2010, 123, 69-76. [CrossRef]

29. Amessis-Ouchemoukh, N.; Ouchemoukh, S.; Meziant, N.; Idiri, Y.; Hernanz, D.; Stinco, C.M.; Rodríguez-Pulido, F.J.; Heredia, F.J.; Madani, K.; Luis, J. Bioactive metabolites involved in the antioxidant, anticancer and anticalpain activities of Ficus carica L., Ceratonia siliqua L. and Quercus ilex L. extracts. Ind. Crops Prod. 2017, 95, 6-17. [CrossRef]

30. Chu, C.-C.; Chen, S.-Y.; Chyau, C.-C.; Fu, Z.-H.; Liu, C.-C.; Duh, P.-D. Protective effect of Djulis (Chenopodium formosanum) and its bioactive compounds against carbon tetrachloride-induced liver injury, in vivo. J. Funct. Foods 2016, 26, 585-597. [CrossRef]

31. Spanogiannopoulos, P.; Bess, E.N.; Carmody, R.N.; Turnbaugh, P.J. The microbial pharmacists within us: A metagenomic view of xenobiotic metabolism. Nat. Rev. Microbiol. 2016, 14, 273-287. [CrossRef] [PubMed]

32. Gouda, S.; Das, G.; Sen, S.K.; Shin, H.-S.; Patra, J.K. Endophytes: A treasure house of bioactive compounds of medicinal importance. Front. Microbiol. 2016, 7, 1538. [CrossRef] [PubMed]

33. Khan, A.L.; Ali, L.; Hussain, J.; Rizvi, T.S.; Al-Harrasi, A.; Lee, I.-J. Enzyme inhibitory radicinol derivative from endophytic fungus Bipolaris sorokiniana LK12, associated with Rhazya stricta. Molecules 2015, 20, 12198-12208. [CrossRef] [PubMed]

34. Nonejuie, P.; Trial, R.M.; Newton, G.L.; Lamsa, A.; Perera, V.R.; Aguilar, J.; Liu, W.-T.; Dorrestein, P.C.; Pogliano, J.; Pogliano, K. Application of bacterial cytological profiling to crude natural product extracts reveals the antibacterial arsenal of Bacillus subtilis. J. Antibiot. 2016, 69, 353-361. [CrossRef] [PubMed]

35. Afiyatullov, S.S.; Kalinovskaya, N.I.; Kuznetsova, T.A.; Ivanova, E.P.; Mikhailov, V.V. Antibiotics from strains of Bacillus pumilus isolated from a marine sponge Dendrilla sp. Chem. Nat. Compd. 1991, 27, 765-766. [CrossRef]

36. Shimojima, Y.; Hayashi, H.; Ooka, T.; Shibukawa, M. Production, isolation and pharmacological studies of AI-77s. Agric. Biol. Chem. 1982, 46, 1823-1829. [CrossRef]

37. Wang, J.; Guleria, S.; Koffas, M.A.G.; Yan, Y. Microbial production of value-added nutraceuticals. Curr. Opin. Biotechnol. 2016, 37, 97-104. [CrossRef] [PubMed]

38. Strobel, G.; Daisy, B. Bioprospecting for microbial endophytes and their natural products. Microbiol. Mol. Biol. Rev. 2003, 67, 491-502. [CrossRef] [PubMed] 
39. Shimojima, Y.; Hayashi, H. 1H-2-benzopyran-1-one derivatives, microbial products with pharmacological activity. Relationship between structure and activity in 6-[[1(S)-(3(S),4-dihydro-8-hydroxy-1-oxo-1H-2-benzopyran-3-yl)-3methylbutyl]-amino]-4(S),5(S)-dihydroxy-6-oxo-3(S)-ammon. J. Med. Chem. 1983, 26, 1370-1374. [CrossRef] [PubMed]

40. Huang, Y.-F.; Li, L.-H.; Tian, L.; Qiao, L.; Hua, H.-M.; Pei, Y.-H. Sg17-1-4, a novel isocoumarin from a marine fungus Alternaria tenuis Sg17-1. J. Antibiot. 2006, 59, 355-357. [CrossRef] [PubMed]

Sample Availability: Samples of the compound are available from the authors.

(C) 2018 by the authors. Licensee MDPI, Basel, Switzerland. This article is an open access article distributed under the terms and conditions of the Creative Commons Attribution (CC BY) license (http://creativecommons.org/licenses/by/4.0/). 